\title{
Detection of Ligand-Substitution Intermediates in the Photoreactions of Bis(2,2'-bipyridine)butanediamineruthenium(II) Complex Using Electrospray Ionization Mass Spectrometry
}

\author{
Ryuichi Arakawa, ${ }^{*}$ Kazuyuki Abe, Tsutomu Abura, and Yasuo Nakabayashi ${ }^{\dagger}$ \\ Department of Applied Chemistry, Kansai University, Suita, Osaka 564-8680 \\ †Chemistry Branch, Faculty of Engineering, Kansai University, Suita, Osaka 564-8680
}

(Received February 20, 2002)

\begin{abstract}
The photolysis of $\left[\mathrm{Ru}(\mathrm{bpy})_{2}(\mathrm{bn})\right]^{2+}$ (bpy $=2,2^{\prime}$-bipyridine, $\mathrm{bn}=1$,4-butanediamine) in acetonitrile and acetone by light of wavelength longer than $420 \mathrm{~nm}$ was studied by electrospray ionization mass spectrometry (ESI-MS). The results were different from those of two other amine complexes, $\left[\mathrm{Ru}(\mathrm{bpy})_{2}(\mathrm{en})\right]^{2+}$ and $\left[\mathrm{Ru}(\mathrm{bpy})_{2}(\mathrm{tn})\right]^{2+}(\mathrm{en}=$ ethylenediamine and $\mathrm{tn}=1,3$-propanediamine). An analysis of the irradiation time course revealed that one end of the bn ligand is quickly dissociated to form a solvent-coordinated complex, $\left[\mathrm{Ru}(\mathrm{bpy})_{2}(\mathrm{bn})(\mathrm{AN})\right]^{2+}(\mathrm{AN}=$ acetonitrile), and its protonated complex, $\left[\mathrm{Ru}(\mathrm{bpy})_{2}(\mathrm{bn}+\mathrm{H})(\mathrm{AN})\right]^{3+}$. These solvent-coordinated complexes were not observed in the photochemical reactions of the en or tn complex. The difference in photolysis is due to the fact that the coordination of the bn ligand in $\left[\mathrm{Ru}(\mathrm{bpy})_{2}(\mathrm{bn})\right]^{2+}$ is less stable than the en or tn ligand. Both the en and tn complexes formed oxygenated complexes, while the bn complex did not form such a complex. This can be explained by the incorporation of singlet oxygen during the photochemical reaction.
\end{abstract}

Several dehydrogenation reactions of aliphatic amines, such as ethylenediamine chelating to $\mathrm{Ru}(\mathrm{II})$ complex, have been studied by chemical oxidation or electrochemical oxidation reactions. ${ }^{1-4}$ These studies have shown that the oxidative dehydrogenation reaction took place first by the oxidation of $\mathrm{Ru}(\mathrm{II})$ to $\mathrm{Ru}$ (III) to form a 17 electron complex, which was then transformed to a diimine complex via a monoimine intermediate. $^{3,5,6,7}\left[\mathrm{Ru}(\mathrm{bpy})_{2} \mathrm{~L}\right]^{2+}$ complexes, where bpy $=2,2^{\prime}$-bipyridine, $\mathrm{L}=$ ehtylenediamine (en), 1,3-propanediamine (tn), or 1,4-butanediamine (bn) $(\mathbf{1}, \mathbf{2}, 3$ in Fig. 1), exhibit strong metalto-ligand charge-transfer (MLCT) absorption peaks at around $450-500 \mathrm{~nm}$ in acetonitrile. Among them, Meyer and coworkers showed the electrolytic oxidation of $\left[\operatorname{Ru}(b p y)_{2}(e n)\right]^{2+}$ to give the diimine complex, ${ }^{3}$ while Ollino and Rest reported the photochemical oxidation of $\left[\mathrm{Ru}(\mathrm{bpy})_{2}(\mathrm{en})\right]^{2+}$ and $\left[\mathrm{Ru}(\mathrm{bpy})_{2^{-}}\right.$

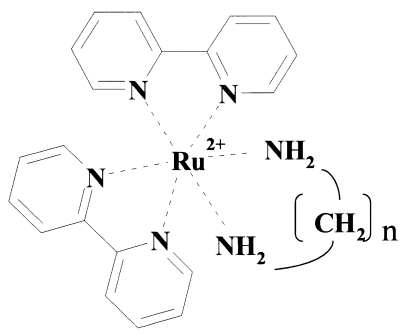

\footnotetext{
$1 \mathrm{n}=2$ : ethylenediamine(en)

$2=3$ : propanediamine $($ tn)

$3=4$ : butanediamine(bn)
}

Fig. 1. Structures of bis(2,2'-bipyridine)diamineruthenium(II) complexes. $(\mathrm{tn})]^{2+}$ to produce diimine complexes. ${ }^{8}$ Although the oxidative dehydrogenation reactions were believed to occur by MLCT excitation, ${ }^{9}$ their expected reaction intermediates, the $\mathrm{Ru}(\mathrm{III})$ complex and the monoimine complex, were too unstable to be isolated or identified; therefore, the reaction pathway to the diimine complex remains unclear.

Electrospray ionization mass spectrometry (ESI-MS), developed by Fenn and coworkers, ${ }^{10-12}$ has become a powerful technique for the detection and identification of reaction products and their intermediates. ${ }^{13-17}$ We previously studied the ESI-MS analysis on the photochemical reaction of $\left[\mathrm{Ru}(\mathrm{bpy})_{2}{ }^{-}\right.$ $(\mathrm{en})]^{2+}$ in acetonitrile. By using an isotope-labeled complex, we were able to confirm that the complex was transformed to the diimine complex via a monoimine intermediate. In addition, we detected a new oxygenated complex, which was shown to be a nitroso-complex from an ${ }^{18} \mathrm{O}_{2}$ labeled experiment $^{18,19}$ (See Scheme 1). We also showed that $\left[\mathrm{Ru}(\mathrm{bpy})_{2}{ }^{-}\right.$ $(\mathrm{tn})]^{2+}$ formed the same type of photochemical reaction product as that of $\left[\mathrm{Ru}(\mathrm{bpy})_{2}(\mathrm{en})\right]^{2+}$, and that none of these photochemical oxygenation reactions occurred in the absence of oxygen.

The photochemical dehydrogenation of the diamine complexes $\left[\operatorname{Ru}(\mathrm{bpy})_{2}(\mathrm{en})\right]^{2+}$ and $\left[\operatorname{Ru}(\mathrm{bpy})_{2}(\mathrm{tn})\right]^{2+}$ leads to the diimine complex via the monoimine complex, and finally transforms to the ligand-substituted product $\left[\mathrm{Ru}(\mathrm{bpy})_{2}(\mathrm{solv})_{2}\right]^{2+}$ with a solvent. The reaction is considered to proceed via the one-electron oxidation of the $\mathrm{Ru}$ (II) complex to a $\mathrm{Ru}$ (III) complex and the intermediate with dissociation of one end of the diamine. However, such reaction intermediates for the ligand substitution process have not been detected for the aliphatic amine complexes. In addition, the reaction pathway to form 


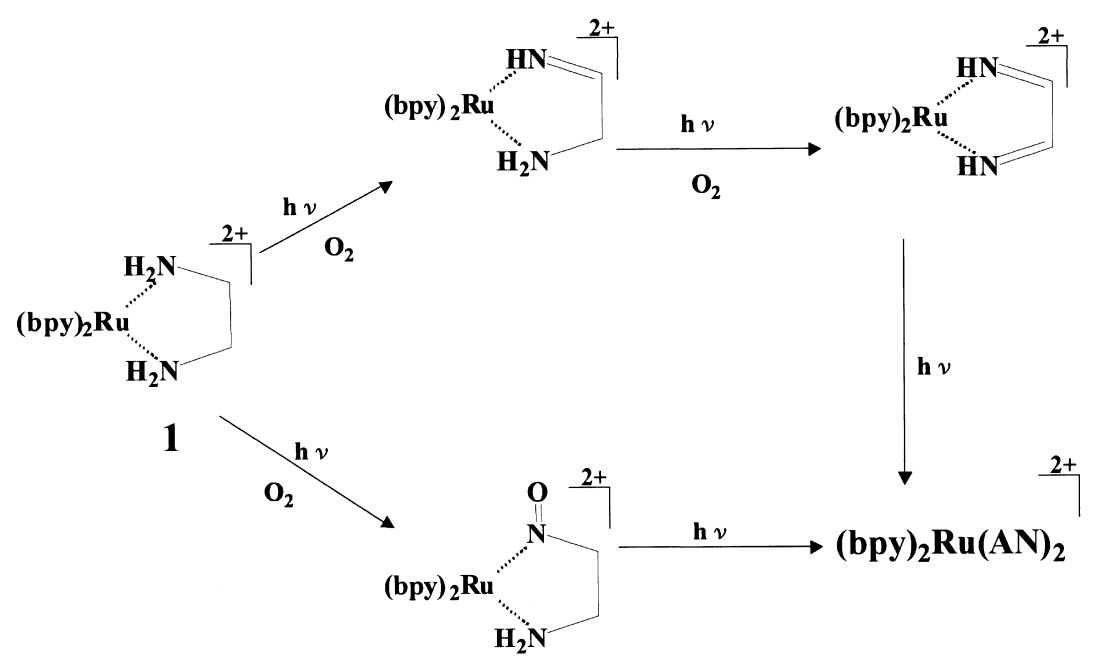

Scheme 1. Photoreaction pathway of $\left[\mathrm{Ru}(\mathrm{bpy})_{2}(\mathrm{en})\right]\left(\mathrm{PF}_{6}\right)_{2}$ in acetonitrile.

the oxygenated complex of the en and tn complexes is still unclear. As an attempt to clarify the reaction mechanism, we carried out the photochemical reaction of $\left[\mathrm{Ru}(\mathrm{bpy})_{2}(\mathrm{bn})\right]^{2+} \mathbf{3}$. Since the diamine ligand in the bn complex is weakly bound to $\mathrm{Ru}(\mathrm{II})$, which is a less-stable structure than that of the en and tn complexes, different photochemical reaction products or pathway may be observed.

\section{Experimental}

$\left[\mathrm{Ru}(\mathrm{bpy})_{2} \mathrm{~L}\right]\left(\mathrm{PF}_{6}\right)_{2}(\mathrm{~L}=\mathrm{en}, \mathrm{tn}$, or bn $)$ was synthesized in a similar manner to a published method ${ }^{3}$ for the en complex. The synthesized bn complex was confirmed by elemental analysis ${ }^{20}$ and ESI-MS. The UV-vis absorption spectra of the bn complex was similar to those of the en and tn complexes.

An ESI-MS analysis was performed by a sector-type mass spectrometer (JEOL-D300) with the ESI interface constructed in our laboratory. Sample solutions were supplied with a flow rate of $2.5 \mu \mathrm{L} / \mathrm{min}$ and sprayed from the tip of a needle biased at $3.5 \mathrm{kV}$ higher than the counter-electrode. MS/MS analysis was carried out with LCQ ion-trap mass spectrometer (Finnigan MAT, San Jose, CA). A high-pressure Xe lamp (150 W) was used to irradiate sample solutions in a quartz reaction cell $(10 \mathrm{~mm} \times 10 \mathrm{~mm} \times 50 \mathrm{~mm})$ at $\lambda>420 \mathrm{~nm}$ using a UV-cutting off filter. The size of the light spot was ca. $5 \mathrm{~mm}$ in diameter. The photon power of the spot was about $0.02 \mathrm{~mW}$. All other light sources were intercepted in the experiments.

The complex was dissolved in acetone or acetonitrile to form $0.2 \mathrm{mM}$ solutions. After the solution was transferred immediately to the quartz cell and irradiated for a given period, the sample solution collected in a syringe was infused into the mass spectrometer for product analysis. Acetonitrile- $d_{3}$ and acetone- $d_{6}$ were used as solvents and analyzed in the same manner. All ESI-mass spectra were obtained in the positive ion mode. Oxygen dissolved in the solvents was removed, if necessary, by a replacement with argon gas.

\section{Results and Discussion}

Photochemical Reactions of $\left[R u(b p y)_{2}(b n)\right]\left(P_{6}\right)_{2}$ in Acetonitrile. Figure 2 shows the mass spectra of $\left[\mathrm{Ru}(\mathrm{bpy})_{2}-\right.$ (bn) $]\left(\mathrm{PF}_{6}\right)_{2} \mathbf{3}$ obtained after photoirradiation for several differ- ent periods. The spectrum obtained before the irradiation (Fig. 2a) yielded the complex ions with removal of one and two counter anions, $\left[\mathrm{Ru}(\mathrm{bpy})_{2}(\mathrm{bn})\right]\left(\mathrm{PF}_{6}\right)^{+}$at $m / z \quad 647$ and $\left[\mathrm{Ru}(\mathrm{bpy})_{2}(\mathrm{bn})\right]^{2+}$ at $\mathrm{m} / \mathrm{z} 251$. The figure at the upper-right in Fig. represents the intensity of the base peak. The $m / z$ value was calculated from ${ }^{102} \mathrm{Ru}$. An enlarged spectrum in the area of $\left[\mathrm{Ru}(\mathrm{bpy})_{2}(\mathrm{bn})\right]\left(\mathrm{PF}_{6}\right)^{+}$ion (the insert in Fig. 2a) showed that the observed isotope distribution is in good agreement with the calculated one (marked solid dots). Because the ESI mass spectrum of the bn complex showed no change for several hours at room temperature, no reaction occurred without light irradiation. The sample solution was prepared under an Ar atmosphere using Ar-purged acetonitrile, and was irradiated for 30 min under the same conditions. There was no photoreaction product in the spectrum obtained after photoirradiation, indicating that photolysis really undergoes in the presence of oxygen.

The spectrum obtained after irradiation for one minute (Fig. 2b) yielded, in addition to the ions observed in Fig. 2a, strong peaks of $\left[\mathrm{Ru}(\mathrm{bpy})_{2}(\mathrm{bn})(\mathrm{AN})\right]\left(\mathrm{PF}_{6}\right)^{+}$at $m / z 688$ and $\left[\mathrm{Ru}(\mathrm{bpy})_{2^{-}}\right.$ (bn)(AN) $]^{2+}$ at $m / z 271.5$ (4 in Scheme 2). These peaks were formed by the dissociation of one end of the bn and the coordination of an acetonitrile (AN) molecule to $\mathrm{Ru}(\mathrm{II})$. Furthermore, two protonated ions $\left[\mathrm{Ru}(\mathrm{bpy})_{2}(\mathrm{bn}+\mathrm{H})(\mathrm{AN})\right]\left(\mathrm{PF}_{6}\right)_{2}{ }^{+}$at $m / z 834$ and $\left[\mathrm{Ru}(\mathrm{bpy})_{2}(\mathrm{bn}+\mathrm{H})(\mathrm{AN})\right]\left(\mathrm{PF}_{6}\right)^{2+}$ at $m / z 344.5$ were observed (5 in Scheme 2). The solvent-coordinated ions were observed only with the bn complex, but not with the en or tn complex, ${ }^{21}$ and appear to be the intermediates of the photoligand-substitution reaction of the aliphatic diamine $\mathrm{Ru}(\mathrm{II})$ complex. These ions were not detected without oxygen in solution. It is unclear how oxygen plays a part in the formation of these ions. The origin of protons is probably a water impurity or the dissociation of acetonitrile $\left(\mathrm{H}^{+}+\mathrm{CH}_{2}=\mathrm{C}=\mathrm{N}^{-}\right)$. A close examination of the enlarged area of $\left[\mathrm{Ru}(\mathrm{bpy})_{2}(\mathrm{bn})(\mathrm{AN})\right]-$ $\left(\mathrm{PF}_{6}\right)^{+}$revealed that neither a monoimine nor a diimine complex was formed, because neither a 2 Da lower nor a 4 Da lower ion can be observed in the insert of Fig. 2b. The isotope distribution of the ions was in good agreement with the calculated one (marked solid dots). The coordination of an acetonitrile molecule to the $\mathrm{Ru}$ (II) center was confirmed by using $\mathrm{CD}_{3} \mathrm{CN}$ 

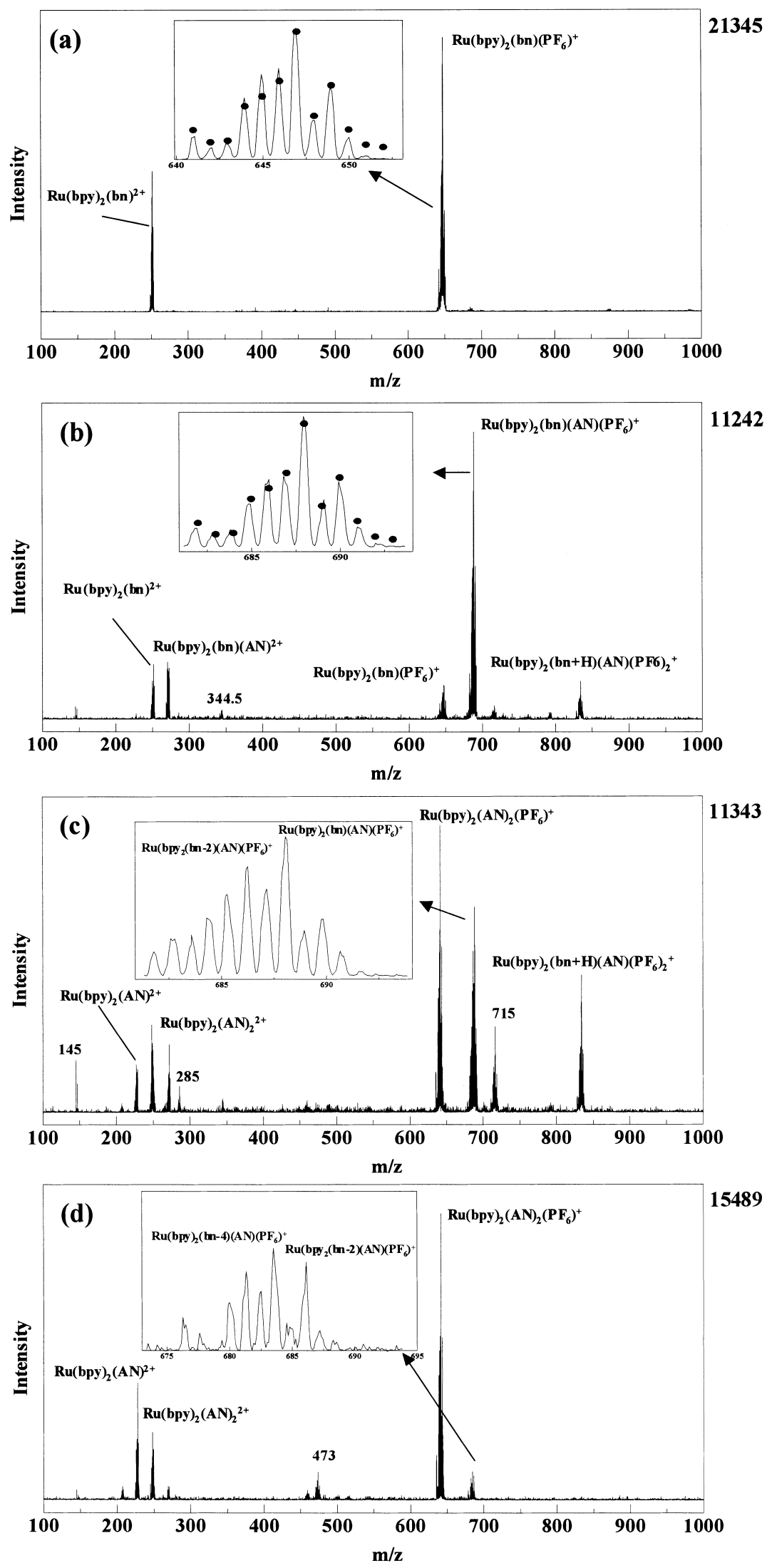

Fig. 2. ESI mass spectra of $\left[\mathrm{Ru}(\mathrm{bpy})_{2}(\mathrm{bn})\right]\left(\mathrm{PF}_{6}\right)_{2}$ in acetonitrile: (a) no irradiation, (b) irradiation $(\lambda>420 \mathrm{~nm})$ for $1 \mathrm{~min}$, (c) for 30 $\min$, and (d) for $3 \mathrm{~h}$. The each spectrum was measured under the same experimental condition. The figure at upper-right represents the intensity of a base peak. 


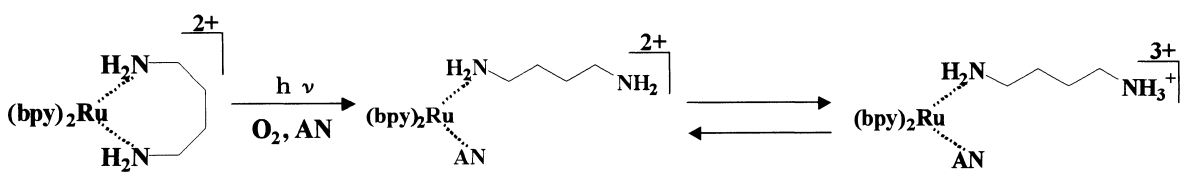

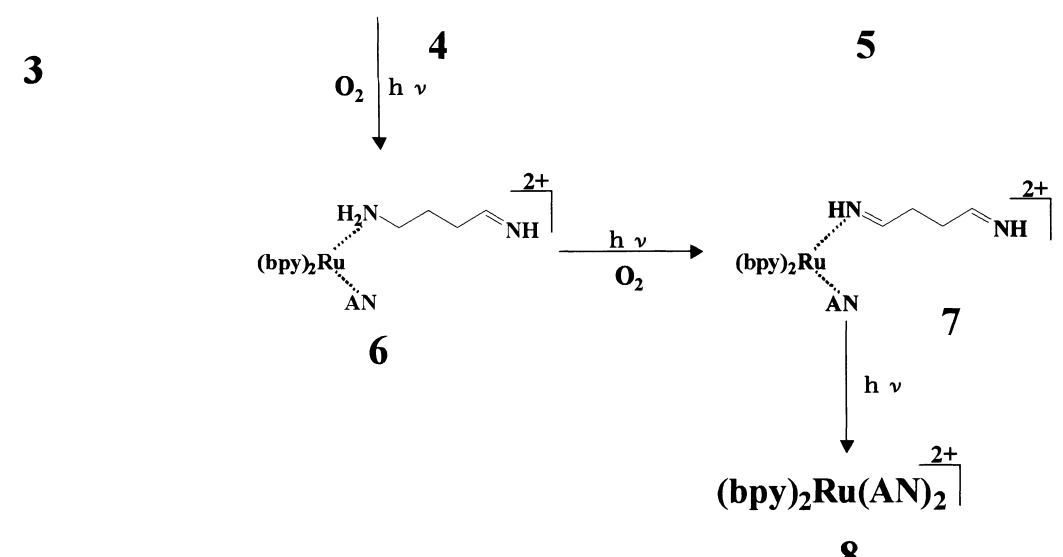

Scheme 2. Photoreaction processes of $\left[\mathrm{Ru}(\mathrm{bpy})_{2}(\mathrm{bn})\right]\left(\mathrm{PF}_{6}\right)_{2}$ in acetonitrile.

Table 1. The Product Ions Observed in the Photoreaction of $\left[\mathrm{Ru}(\mathrm{bpy})_{2} \mathrm{~L}\right]\left(\mathrm{PF}_{6}\right)_{2}(\mathrm{~L}=\mathrm{en}$, tn, and bn) in Acetonitrile

\begin{tabular}{|c|c|c|c|c|c|}
\hline \multirow{2}{*}{$\begin{array}{l}\text { Compounds }^{\mathrm{a})} \\
{\left[\mathrm{Ru}(\mathrm{bpy})_{2} \mathrm{~L}\right]^{2+}}\end{array}$} & \multicolumn{5}{|c|}{ Observed photoreaction products } \\
\hline & Monoimine & Diimine & Solvent coordinated & Protonated complex & Adducts of oxygen $^{b)}$ \\
\hline en & {$\left[\mathrm{Ru}(\mathrm{bpy})_{2}(\mathrm{en}-2)\right]^{2+}$} & {$\left[\operatorname{Ru}(\mathrm{bpy})_{2}(\mathrm{en}-4)\right]^{2+}$} & $\mathrm{ND}^{\mathrm{c})}$ & ND & {$\left[\mathrm{Ru}(\mathrm{bpy})_{2}(\mathrm{en}+14)\right]^{2+}$} \\
\hline tn & {$\left[\mathrm{Ru}(\mathrm{bpy})_{2}(\mathrm{tn}-2)\right]^{2+}$} & {$\left[\operatorname{Ru}(b p y)_{2}(\operatorname{tn}-4)\right]^{2+}$} & $\mathrm{ND}^{\mathrm{d})}$ & ND & {$\left[\mathrm{Ru}(\mathrm{bpy})_{2}(\mathrm{tn}+14)\right]^{2+}$} \\
\hline bn & $\begin{array}{l}{\left[\mathrm{Ru}(\mathrm{bpy})_{2^{-}}\right.} \\
(\mathrm{bn}-2)(\mathrm{AN})]^{2+}\end{array}$ & $\begin{array}{l}{\left[\mathrm{Ru}(\mathrm{bpy})_{2^{-}}\right.} \\
(\mathrm{bn}-4)(\mathrm{AN})]^{2+}\end{array}$ & {$\left[\mathrm{Ru}(\mathrm{bpy})_{2}(\mathrm{bn})(\mathrm{AN})\right]^{2+}$} & $\begin{array}{l}{\left[\mathrm{Ru}(\mathrm{bpy})_{2^{-}}\right.} \\
(\mathrm{bn}+\mathrm{H})(\mathrm{AN})]\left(\mathrm{PF}_{6}\right)_{2}{ }^{+}\end{array}$ & ND \\
\hline
\end{tabular}

a) bpy $=2,2^{\prime}$-bipyridine, en = ethylenediamine, tn $=1,3$-propanediamine, $\quad$ bn $=1,4$-butanediamine, $\quad \mathrm{AN}=$ acetonitrile.

b) $\left[\mathrm{Ru}(\mathrm{bpy})_{2}(\mathrm{~L}+14)\right]^{2+}$ represents the nitroso-complex ion that is $14 \mathrm{Da}$ larger than $\left[\mathrm{Ru}(\mathrm{bpy})_{2} \mathrm{~L}\right]^{2+}$. c) No detection. d) Ref. 21

as the solvent, in which $\left[\mathrm{Ru}(\mathrm{bpy})_{2}(\mathrm{bn})(\mathrm{AN})\right]\left(\mathrm{PF}_{6}\right)^{+}$appeared as a 3 Da higher ion.

The spectrum obtained after irradiation for $30 \mathrm{~min}$ (Fig. 2c) yielded a base peak $\left[\mathrm{Ru}(\mathrm{bpy})_{2}(\mathrm{AN})_{2}\right]\left(\mathrm{PF}_{6}\right)^{+}$at $\mathrm{m} / \mathrm{z}$ 641, in which the bn ligand had been eliminated and replaced by two AN molecules. The peaks at $m / z 285$ and 715 were assigned to $\left[\mathrm{Ru}(\mathrm{bpy})_{3}\right]^{2+}$ and $\left[\mathrm{Ru}(\mathrm{bpy})_{3}\right]\left(\mathrm{PF}_{6}\right)^{+}$, respectively. The other ions were the same as those which appeared in the spectrum after irradiation for one minute. However, the enlarged spectrum in the area of $\left[\mathrm{Ru}(\mathrm{bpy})_{2}(\mathrm{bn})(\mathrm{AN})\right]\left(\mathrm{PF}_{6}\right)^{+}(\mathrm{m} / z$ 688) revealed increased intensity of the $2 \mathrm{Da}$ lower ion, namely the presence of the monoimine $\left[\mathrm{Ru}(\mathrm{bpy})_{2}(\mathrm{bn}-2)(\mathrm{AN})\right]\left(\mathrm{PF}_{6}\right)^{+}$ $\left(m / z\right.$ 686). The ratio of $\left[\mathrm{Ru}(\mathrm{bpy})_{2}(\mathrm{bn})(\mathrm{AN})\right]\left(\mathrm{PF}_{6}\right)^{+}$to $[\mathrm{Ru}-$ $\left.(\mathrm{bpy})_{2}(\mathrm{bn}-2)(\mathrm{AN})\right]\left(\mathrm{PF}_{6}\right)^{+}$was calculated to be $6: 4$ from the isotope distributions of the mixture of two ions. The bidentate monoimine complex $\left[\mathrm{Ru}(\mathrm{bpy})_{2}(\mathrm{~L}-2)\right]^{2+}$ was detected with the en or tn complex, but not with the bn complex. Instead, the bn complex yielded the solvent-coordinated complex $\left[\mathrm{Ru}(\mathrm{bpy})_{2}(\mathrm{bn})(\mathrm{AN})\right]\left(\mathrm{PF}_{6}\right)^{+} . \quad\left[\mathrm{Ru}(\mathrm{bpy})_{2}(\mathrm{bn}-2)(\mathrm{AN})\right]\left(\mathrm{PF}_{6}\right)^{+}$ was not observed after $1 \mathrm{~min}$ of irradiation, but appeared at 30 min of irradiation.

After irradiation for $3 \mathrm{~h}$ of (Fig. 2d), the spectrum was similar to that after irradiation for $30 \mathrm{~min}$. $\left[\mathrm{Ru}(\mathrm{bpy})_{2}(\mathrm{AN})_{2}\right]\left(\mathrm{PF}_{6}\right)^{+}$ was the base peak; however, the enlarged spectrum near at $\mathrm{m} / \mathrm{z}$ 688 revealed the absence of the ion $\left[\mathrm{Ru}(\mathrm{bpy})_{2}(\mathrm{bn})(\mathrm{AN})\right]\left(\mathrm{PF}_{6}\right)^{+}$ and the presence of the $2 \mathrm{Da}$ lower ion, $\left[\mathrm{Ru}(\mathrm{bpy})_{2}(\mathrm{bn}-2)\right.$ $(\mathrm{AN})]\left(\mathrm{PF}_{6}\right)^{+}$, and the $4 \mathrm{Da}$ lower ion, $\left[\mathrm{Ru}(\mathrm{bpy})_{2}(\mathrm{bn}-4)-\right.$
(AN) $]\left(\mathrm{PF}_{6}\right)^{+}$. The spectrum also showed that the protonated ion, $\left[\mathrm{Ru}(\mathrm{bpy})_{2}(\mathrm{bn}+\mathrm{H})(\mathrm{AN})\right]\left(\mathrm{PF}_{6}\right)_{2}{ }^{+}(\mathrm{m} / z$ 834), had completely disappeared. Table 1 summarizes the product ions observed in the photoreaction of $\left[\mathrm{Ru}(\mathrm{bpy})_{2} \mathrm{~L}\right]\left(\mathrm{PF}_{6}\right)_{2}(\mathrm{~L}=\mathrm{en}$, tn, and bn) during the irradiation.

A MS/MS experiment with an ion-trap-type mass spectrometer LCQ was performed to obtain structural information on $\left[\mathrm{Ru}(\mathrm{bpy})_{2}(\mathrm{bn})(\mathrm{AN})\right]^{2+}$ 4. The full-scan spectrum after irradiation for 3 min yielded the solvent-coordinated ions: $\left[\mathrm{Ru}(\mathrm{bpy})_{2}-\right.$ $(\mathrm{bn})(\mathrm{AN})]^{2+}, \quad\left[\mathrm{Ru}(\mathrm{bpy})_{2}(\mathrm{bn})(\mathrm{AN})\right]\left(\mathrm{PF}_{6}\right)^{+}, \quad$ and $\quad\left[\mathrm{Ru}(\mathrm{bpy})_{2^{-}}\right.$ $(\mathrm{bn}+\mathrm{H})(\mathrm{AN})]\left(\mathrm{PF}_{6}\right)_{2}{ }^{+}$. These ions were not detected without irradiation. If they are solvent-attached complexes in which $\mathrm{AN}$ is not coordinated directly to $\mathrm{Ru}(\mathrm{II})$, such solvent-attached complexes formed from ion-molecule reactions in the LCQ ion source could be detected without irradiation. In addition, the MS/MS results of $\left[\mathrm{Ru}(\mathrm{bpy})_{2}(\mathrm{bn})(\mathrm{AN})\right]^{2+}$ showed that a fragment ion, $\left[\mathrm{Ru}(\mathrm{bpy})_{2}(\mathrm{bn})\right]^{2+}$, with the removal of AN appeared at a collision energy of $15 \%$ (indicated by LCQ's own way), half of the parent ions dissociated to fragments at an energy of $20 \%$, and all of the parent ions dissociated at $25 \%$ and another fragment was not observed. The MS/MS spectrum of $\left[\mathrm{Ru}(\mathrm{bpy})_{2}(\mathrm{bn})(\mathrm{AN})\right]\left(\mathrm{PF}_{6}\right)^{+}$showed the same result, and yielded an additional fragment, $\left[\mathrm{Ru}(\mathrm{bpy})_{2}(\mathrm{bn})\right](\mathrm{F})^{+}(\mathrm{m} / \mathrm{z}$ 521). In the MS/MS of the protonated ion, $\left[\mathrm{Ru}(\mathrm{bpy})_{2}(\mathrm{bn}+\mathrm{H})(\mathrm{AN})\right]-$ $\left(\mathrm{PF}_{6}\right)_{2}{ }^{+},\left[\mathrm{Ru}(\mathrm{bpy})_{2}(\mathrm{bn})(\mathrm{AN})\right]\left(\mathrm{PF}_{6}\right)^{+}$was preferentially generated by the removal of neutral $\mathrm{HPF}_{6}$, and thus the dissociation of AN was not detected. It is concluded from the above results 


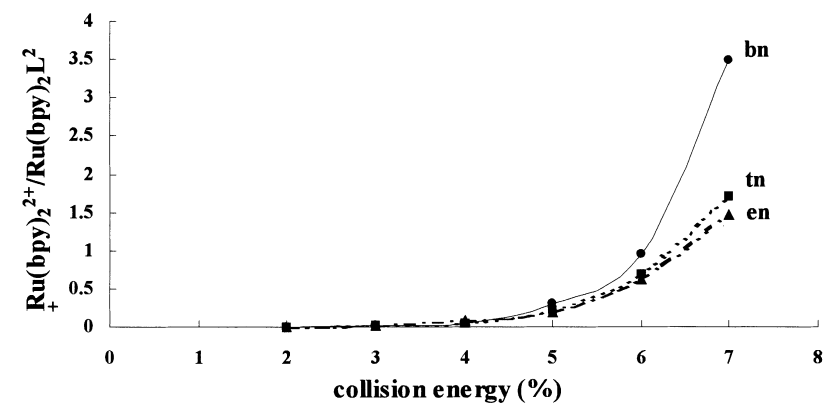

Fig. 3. Intensity of the fragment ion $\left[\mathrm{Ru}(\mathrm{bpy})_{2}\right]^{2+}$ vs collision energy in the MS/MS experiment of $\left[\mathrm{Ru}(\mathrm{bpy})_{2} \mathrm{~L}\right]^{2+}$ $(\mathrm{L}=\mathrm{en}, \mathrm{tn}$, and bn).

that the $\mathrm{AN}$ solvent is actually coordinated to $\mathrm{Ru}(\mathrm{II})$ in the complex.

A previous study for the en and tn complexes ${ }^{19}$ showed that an oxidized complex, $\left[\mathrm{Ru}(\mathrm{bpy})_{2}(\mathrm{en}+14)\right]^{2+}$, in which the mass is 14 greater than that of $\left[\mathrm{Ru}(\mathrm{bpy})_{2}(\mathrm{en})\right]^{2+}$, was detected, and its structure was confirmed to be a nitroso-complex by a deuterium-labeling experiment with $\left[\mathrm{Ru}(\mathrm{bpy})_{2}\left\{\mathrm{H}_{2} \mathrm{~N}-\left(\mathrm{CD}_{2}\right)_{2}-\right.\right.$ $\left.\left.\mathrm{NH}_{2}\right\}\right]^{2+}$. It is important to note that such a nitroso-complex was not observed with the bn complex. The reason is ascribed to an unstable structure of the bn complex; the bn ligand is less strongly coordinated to $\mathrm{Ru}$ (II) than the en and tn. This fact was confirmed by an MS/MS study of $\left[\mathrm{Ru}(\mathrm{bpy})_{2} \mathrm{~L}\right]^{2+}(\mathrm{L}=\mathrm{en}$, tn, and bn), as shown in Fig. 3. The removal of the bn ligand most likely occurred at any collision energy to form $\left[\mathrm{Ru}(\mathrm{bpy})_{2}\right]^{2+}$ among the complex. Therefore, it was likely that one end of the bn would be easily dissociated by irradiation and an AN molecule coordinated to form a solvent-coordinated complex $\left[\mathrm{Ru}(\mathrm{bpy})_{2}(\mathrm{bn})(\mathrm{AN})\right]^{2+}$; namely, the excitation energy from the irradiation is used for intramolecular structural reorganization. On the other hand, the excitation energy in the irradiation of the en and tn complexes can be used for the electronic transition of the oxygen molecule in the solution to form singlet oxygen (the ${ }^{3} \mathrm{O}_{2} \rightarrow{ }^{1} \mathrm{O}_{2}$ transition energy is ca. $92 \mathrm{~kJ} / \mathrm{mol}$ ) ${ }^{22}$. The singlet oxygen will react with the complexes to form nitrosocomplexes.

Based on the above results of the irradiation time course, the photochemical reaction pathway of the bn complex is proposed as shown in Scheme 2. One end of the bn ligand is first cleaved by photo-excitation to form the solvent-coordinated complex $\mathbf{4}$, or the protonated ion $\mathbf{5}$. The complex is oxidized by molecular oxygen to form the monoimine complex $\mathbf{6}$. Moreover, complex 6 can be converted to the diimine 7, and the final product of the photochemical reaction is complex $\mathbf{8}$, in which the ligand is substituted by two molecules of acetonitrile.

The photosensitivity for the en, tn and bn complexes is compared in Fig. 4. An equimolar mixed solution of the en, th and bn complexes was irradiated in acetonitrile for a given period of time. The intensities of the parent ions surviving without dissociation in the solution, as expressed by the sum intensity of $1+$ and $2+$ ions, are plotted as a function of irradiation time. The detection sensitivity of ESI-MS for the en complex is lower than that for the th or the bn complex (see the relative intensities at zero irradiation period in Fig. 4); the reason was

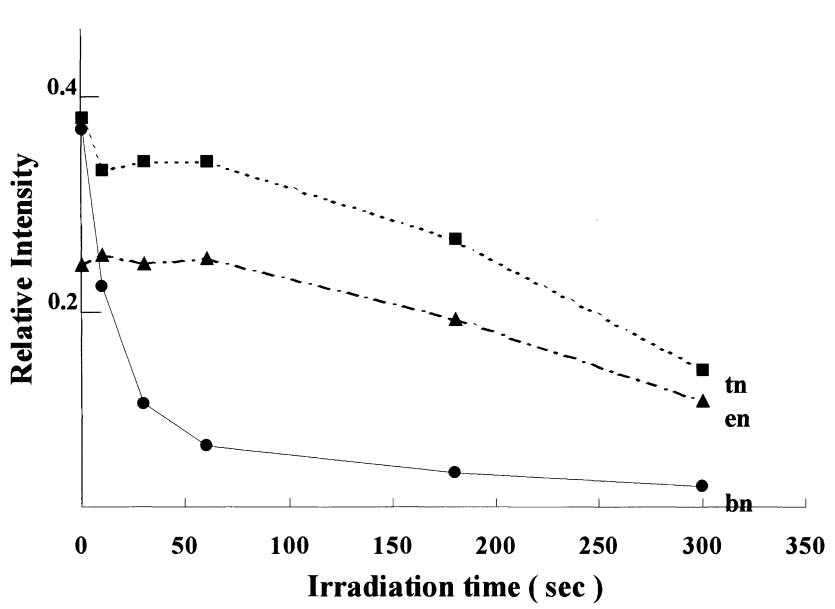

Fig. 4. Comparison of photosensitivity between $\left[\mathrm{Ru}(\mathrm{bpy})_{2} \mathrm{~L}\right]-$ $\left(\mathrm{PF}_{6}\right)_{2}(\mathrm{~L}=\mathrm{en}$, tn or bn) in acetonitrile. An equimolar mixed solution of the en, tn and bn complexes was irradiated for a given period of time. Intensity of a parent ion without dissociation, as expressed by the sum intensity of $1+$ and $2+$ ions, is plotted as a function of irradiation time.

unclear. The decrease in the intensities of the parent ions just corresponds to the increase in the photosensitivity. Therefore, the photosensitivity in acetonitrile was found to be en $\leqq$ tn $<<$ bn. Specifically the effective reactivity for the bn complex may be due to the unstable structure.

Photochemical Reaction of $\left[\mathrm{Ru}(\mathrm{bpy})_{2}(\mathrm{bn})\right]\left(\mathrm{PF}_{6}\right)_{2}$ in Acetone. In the photochemical reaction of the bn complex $\mathbf{3}$ in acetonitrile, the protonated ion $\mathbf{5}$ was detected. In order to confirm the structure of the protonated ion, a photochemical reaction in acetone was performed. It is well known that an amino function reacts quickly with a carbonyl group to form an imine by nucleophilic condensation. For example, we found that a $0.2 \mathrm{mM}$ solution of 1,4-butanediamine in acetone yielded a single peak of a diimine $[\mathrm{bn}+80+\mathrm{H}]^{+}$at $m / z 169$ in the ESI mass spectrum immediately after the preparation. Therefore, it is expected that if a complex such as $\mathbf{4}$ has a free amino-function, nucleophilic condensation would occur. On the other hand, no such condensation would occur if the complex is a protonated amine cation, as in the complex $\mathbf{5}$, which is much less nucleophilic than the amino function.

The results from the photoreaction of the bn complex in acetone are shown in Fig. 5. The spectrum obtained before the irradiation (Fig. 5a) showed no condensation between the diamine ligand and acetone. Namely, the amine that coordinates to the metal center cannot undergo condensation. The spectrum obtained after irradiation for $30 \mathrm{sec}$ (Fig. 5b) yielded, in addition to two complex ions, $\left[\mathrm{Ru}(\mathrm{bpy})_{2}(\mathrm{bn})\right]^{2+}$ at $\mathrm{m} / \mathrm{z} 251$ and $\left[\mathrm{Ru}(\mathrm{bpy})_{2}(\mathrm{bn})\right]\left(\mathrm{PF}_{6}\right)^{+}$at $\mathrm{m} / z$ 647, two intense ions, $\left[\mathrm{Ru}(\mathrm{bpy})_{2}{ }^{-}\right.$ $(\mathrm{bn}+40)]^{2+}$ at $m / z 271$ and $\left[\mathrm{Ru}(\mathrm{bpy})_{2}(\mathrm{bn}+40)\right]\left(\mathrm{PF}_{6}\right)^{+}$at $m / z$ 687 , where the notation $(b n+40)$ represents the ligand being 40 mass units higher than the bn, $\mathrm{H}_{2} \mathrm{~N}-\left(\mathrm{CH}_{2}\right)_{4}-\mathrm{N}=\mathrm{C}\left(\mathrm{CH}_{3}\right)_{2}$. These ions were formed from rechelation after the dissociation of one end of the bn and condensation with an acetone solvent. Moreover, the spectrum showed two significant ions, $\left[\mathrm{Ru}(\mathrm{bpy})_{2}(\mathrm{bn}+\mathrm{H})(\mathrm{AC})\right]\left(\mathrm{PF}_{6}\right)_{2}{ }^{+}$at $m / z 849$ and $\left[\mathrm{Ru}(\mathrm{bpy})_{2}(\mathrm{bn}\right.$ $+\mathrm{H}+40)(\mathrm{AC})]\left(\mathrm{PF}_{6}\right)_{2}{ }^{+}$at $m / z$ 889, where $\mathrm{AC}$ represents an 

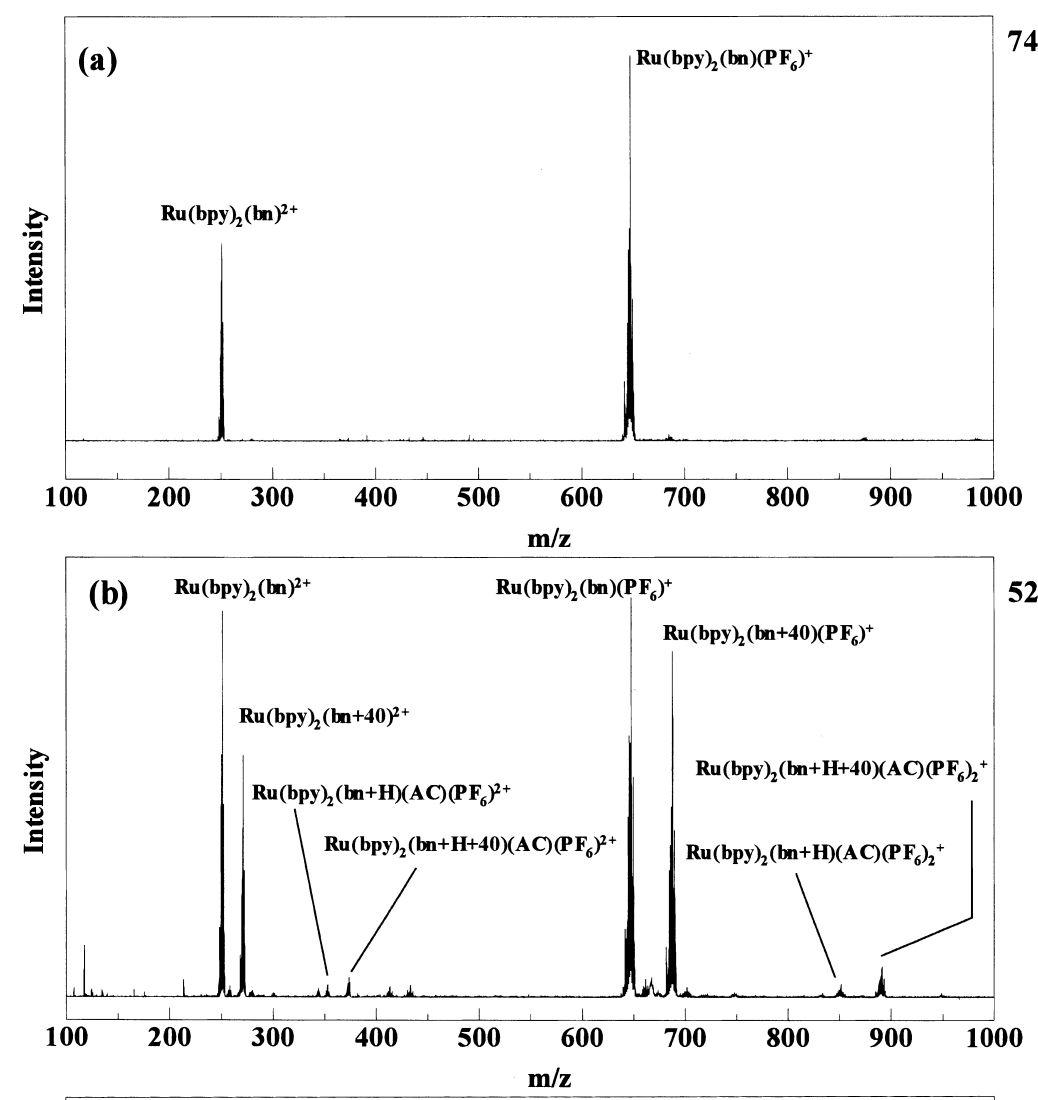

52992

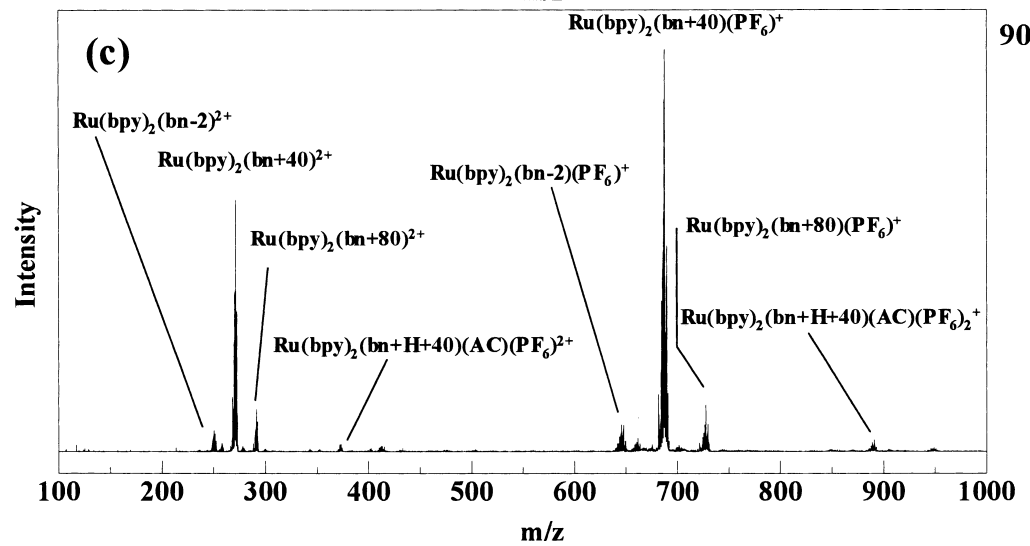

Fig. 5. ESI mass spectra of $\left[\mathrm{Ru}(\mathrm{bpy})_{2}(\mathrm{bn})\right]\left(\mathrm{PF}_{6}\right)_{2}$ in acetone: (a) no irradiation, (b) irradiation $(\lambda>420 \mathrm{~nm})$ for $30 \mathrm{~s}$, and (c) for 5 $\min$.

acetone molecule. The detection of these two ions suggested the presence of the protonated amine cation.

The spectrum obtained after 5 min of irradiation (Fig. 5c) yielded, in addition to the ions obtained after $30 \mathrm{sec}$ of irradiation, ions from the condensation of two amino functions in the complexes $\left[\mathrm{Ru}(\mathrm{bpy})_{2}(\mathrm{bn}+80)\right]^{2+}$ at $\mathrm{m} / \mathrm{z} 291$ and $\left[\mathrm{Ru}(\mathrm{bpy})_{2^{-}}\right.$ $(\mathrm{bn}+80)]\left(\mathrm{PF}_{6}\right)^{+}$at $m / z$ 727. Condensation in those ions was confirmed by using acetone- $d_{6}$ as the solvent; for example, the ion $\left[\mathrm{Ru}(\mathrm{bpy})_{2}(\mathrm{bn}+40)\right]^{2+}$ transformed to $\left[\mathrm{Ru}(\mathrm{bpy})_{2}(\mathrm{bn}+\right.$ 46) $]^{2+}$ in acetone- $d_{6}$.

Based on the above results, the photolysis in acetone can be summarized as follows. The condensation of the diamine ligand with acetone occurred only with the bn complex, but not with both the en and tn complexes. Therefore, it is concluded that the rate of rechelation for the en and tn ligands is much faster than that of the condensation, even though the chelating en and tn ligands are cleaved by the photochemical reaction. The photochemical products of the en and tn complexes in acetone were the same as those in acetonitrile. The solvent-coordinated complexes in acetone were detected only in the protonated state, which is different from that in acetonitrile.

\section{Conclusion}

The $\left[\mathrm{Ru}(\mathrm{bpy})_{2}(\mathrm{bn})\right]\left(\mathrm{PF}_{6}\right)_{2}$ complex is less stable against dissociation of the diamine than its analogs of the en and tn complexes. From the ESI-MS study we found that the photochemical reaction of the bn complex proceeds differently from those of the en and tn complexes. In the photo-oxidative dehydroge- 
nation, (1) the solvent-coordinated complex with dissociation of one end of the diamine ligand and its protonated ion, which had not been detected in the reaction of the en and tn complexes before, were successfully detected with the bn complex. (2) We have shown that the proton was added to the amine group of the bn ligand from a study of the photochemical reaction in acetone. (3) The oxygenated nitroso-complex, which had been found in the photoreaction of the en and tn complexes, was not found with the bn complex. The mechanism of nitroso-complex formation can be explained by the involvement of the singlet oxygen.

The authors thank Dr. H. Ishida of Inoue Photochirogenesis ERATO JST for helpful discussion. This work was supported by CREST of JST (Japan Science and Technology) and by a Grant-in-Aid for Scientific Research from the Ministry of Education, Science, Sports and Culture.

\section{References}

1 B. C. Lane, J. E. Lester, and F. J. Basolo, J. Chem. Soc. D, 1618 (1971).

2 D. F. Mahoney and J. K. Beattie, Inorg. Chem., 12, 2561 (1973).

3 G. M. Brown, T. R. Weaver, F. R. Keene, and T. J. Meyer, Inorg. Chem., 15, 190 (1976).

4 H. Elsbernd and J. K. Beattie, J. Chem. Soc. A, 2598 (1970).

5 C. P. Guengerich and K. Schug, J. Am. Chem. Soc., 99, 3298 (1977).

6 G. G. Christoph and V. L. Goedken, J. Am. Chem. Soc., 95, 3869 (1973).

7 I. P. Evans, G. W. Everett, and A. M. Sargeson, J. Am. Chem. Soc., 98, 8041 (1976).
8 M. A. Ollino and A. J. Rest, J. Photochem. Photobiol. A: Chem., 69, 73 (1992).

9 K. Kalyanasundaram, Coord. Chem. Rev., 46, 159 (1982).

10 M. Yamashita and J. B. Fenn, J. Phys. Chem., 88, 4671 (1984).

11 J. B. Fenn, M. Mann, C. K. Meng, S. K. Wang, and C. Whitehouse, Science, 246, 64 (1989).

12 J. B. Fenn, M. Mann, C. K. Meng, and S. K. Wang, Mass. Spectrosc. Rev., 9, 37 (1990).

13 B. C. Gilbert, N. W. J. Kamp, J. R. L. Smith, and J. Oakes, J. Chem. Soc., Perkin Trans. 2, 1841 (1998).

14 K. B. Jansen, C. J. Mckenzie, L. P. Nielsen, J. Z. Pedersen, and H. M. Svendsen, Chem. Commun., 1999, 1313.

15 S. Takara, S. Ogo, Y. Watanabe, K. Nishikawa, I. Kinoshita, and K. Isobe, Angew. Chem., Int. Ed., 38, 3051 (1999).

16 R. Arakawa, S. Tachiyashiki, and T. Matsuo, Anal. Chem., 67, 4133 (1995).

17 M. Bonchio, G. Licini, G. Modena, O. Bortolini, S. Moro, and W. A. Nugent, J. Am. Chem. Soc., 121, 6258 (1999).

18 R. Arakawa, S. Mimura, G. Matsubayashi, and T. Matsuo, Inorg. Chem., 35, 5725 (1996).

19 R. Arakawa, F. Matsuda, G. Matsubayashi, and T. Matso, J. Am. Soc. Mass Spectrom., 8, 713 (1997).

20 Yields for the en, tn, and bn complexes are 36\%, 45\%, and $21 \%$ respectively. Elemental analysis for the bn complexes, Calcd for $\mathrm{C}_{24} \mathrm{H}_{28} \mathrm{~F}_{12} \mathrm{~N}_{6} \mathrm{P}_{2} \mathrm{Ru}$ : C, 36.42; H, 3.57; N, $10.62 \%$, found: $\mathrm{C}$, $35.99 ; \mathrm{H}, 3.57$; N, $10.62 \%$.

21 The solvent-coordinated complexes $\mathrm{Ru}(\mathrm{bpy})_{2}(\mathrm{tn})(\mathrm{AN})^{2+}$ and $\mathrm{Ru}(\mathrm{bpy})_{2}(\mathrm{tn}+14)(\mathrm{AN})^{2+}$ formed by irradiation were able to be detected in the low intensity by on-line ESI-MS analysis (Ref. $18)$.

22 "Singlet Molecular Oxygen," ed by A. P. Schaap, Wiley (1976); "Singlet Oxygen," ed by H. H. Wasserman and R. W. Murray, Academic Press (1979). 